\title{
Analyze of Physical Activity and Quality of Life on Breast Cancer Patients with Bone Metastases
}

\section{Kemik Metastazı Olan Meme Kanserli Hastalarda Fiziksel Aktivite Düzeyi Ve Yaşam Kalitesinin Değerlendirilmesi}

\author{
Ahmet Yıldırım', Mehmet Ali Eryılmaz ${ }^{2}$ \\ ${ }^{1}$ Selçuk Üniversitesi Tıp Fakültesi, Ortopedi ve Travmatoloji Anabilim Dalı, Konya, Türkiye \\ ${ }^{2}$ Sağlık Bilimleri Üniversitesi Konya Eğitim ve Araştırma Hastanesi, Aile Hekimliği Anabilim Dalı, Konya, \\ Türkiye
}

\section{ÖZET}

Giriş ve Amaç: Meme kanseri, halen kadınlarda dünyada en sık görülen kanser tipi olup; yine gelişmiş ve gelişmekte olan ülkelerde kadınlarda kansere bağlı ölüm nedenleri içerisinde ilk sırada yer almaktadır. Cerrahi ve cerrahi dışı tedaviler yanında, kanserli hastalarda yaşam kalitesinin artııılması oldukça önemlidir. Çalışmamızda kemik metastazı olan meme kanserli hastalarda fiziksel aktivite düzeyi ve yaşam kalitesinin değerlendirilmesi amaçlanmaktadır.

Yöntem ve Gereçler: Kemik metastazı olan ve olmayan meme kanseri ile takip edilen 100 hastada Uluslararası Fiziksel Aktivite Anketi ve kısa form-36 yaşam kalitesi ölçeği yardımı ile kemik metastazı olan ve olmayan hastaların fiziksel aktivite düzeylerinin ve yaşam kalitelerinin belirlenmesini amaçlayan kesitsel bir çalışmadır. Bulgular: Kemik metastazı olmayan hastaların kemik metastazı olan hastalara göre fiziksel olarak daha aktif olduğu istatistiksel olarak saptanmıştır Kısa Form-36'nın alt ölçeklerine göre karşılaştırılmasında kemik metastazı olmayan hastaların fiziksel fonksiyon, fiziksel rol güçlüğü, ağrı, genel sağlık, vitalite (enerji), sosyal fonksiyon, emosyonel güçlük, mental sağlık puan ortalamalarının kemik metastazı olan hastalara göre istatistiksel olarak anlamlı derecede yüksek olduğu saptanmıştır $(\mathrm{p}<0.001)$.

Tartışma ve Sonuç: Kanser tedavisi almalarına rağmen kemik metastazı olmayan grupta, kemik metastazı olanlara göre fiziksel aktivite ve yaşam kalitesi oranının her kategoride anlamlı olarak yüksek olduğu görülmüş ve patolojik kırıkları olmasa da kemik metastazı sonrası hastaların fiziksel aktivite düzeylerinin ve yaşam kalitesinin düştüğü anlaşılmıştır.

Anahtar Kelimeler: Meme kanseri, metastaz, yaşam kalitesi, egzersiz, fiziksel aktivite

\begin{abstract}
Introduction: Breast cancer is still the most common type of neoplasm in the world. It is also the first reason of cancer-related death on women in developed and developing countries. In addition to surgical and non-surgical treatment, it is important to improve the quality of life in cancer patients. The aim of this study is to evaluate the physical activity level and quality of life on breast cancer patients with bone metastasis. Methods: A cross-sectional studywas done that aimed determining the physical activity levels and quality of life of patients with and without bone metastasis. International Physical Activity Questionnaire (short) and short form36 quality of life questionnaire were used for 100 breast cancer patients.

Results: It was found that patients without bone metastasis were physically more active than patients with bone metastases. In comparison of subscales of Short Form-36; physical functioning, role functioning, pain, general health, vitality (energy), social function, The mean scores of emotional health and mental health scores were found to be significantly higher in the without bone metastases group ( $\mathrm{p}<0.001)$.

Discussion and Conclusion: In this study, it has been shown that though the cancer treatment, the ratio of physical activity and quality of life was significantly higher in the group without bone metastasis compared to those with bone metastasis and it was found that the physical activity levels and quality of life of the patients after bone metastasis were found to be decreased.
\end{abstract}

Keywords: Breast cancer, neoplasm metastasis, quality of life, exercise, physical functioning 


\section{GÍRIS}

Son 30 yıl içinde meme kanserinin erken tanı ve tedavisindeki gelişmeler nedeniyle, meme kanseri tanısı alan pek çok hastaya farklı tedavi seçenekleri sunulmakta ve hastalarda tanı sonrası uzun yaşam süreleri gözlenmektedir (1). Meme kanseri tanısı konulmuş pek çok hastada tedavi sonrası normal aktivite düzeyi ve yaşam kalitesi beklenmektedir (2). Tedavi seçenekleri her ne kadar gelişme gösterse de meme kanseri, halen kadınlarda dünyada en sık görülen kanser tipi olup; yine gelişmiş ve gelişmekte olan ülkelerde kadınlarda kansere bağlı ölüm nedenleri içerisinde ilk sırada yer almaktadır (3).

Dünya çapında her yıl yaklaşık 1,7 milyon yeni meme kanseri tanıs1 konulmakta ve yine yaklaşık yarım milyon insan her yıl meme kanseri nedeniyle yaşamını yitirmektedir (3). Meme kanserinde ölüm nedeni olarak, kansere ait lokal bulgulardan çok uzak organ metastazlarına bağlı komplikasyonlar suçlanmaktadır (4). Meme kanseri uzun süre sessiz kalabilmesi nedeniyle çok uzun y1llar metastaz riski taşımaktadır. Hastaların \%5'inde ilk tanı aldıklarında metastaz mevcutken, \%70'inde ise tanı sonras 1 metastaz riski mevcuttur (3-5). Metastaz bölgeleri içerisinde ise kemik ilk sırada yer almakta olup, metastatik meme kanserli hastaların yaklaşık \%70'inde kemik metastazı görülmektedir (6).

Bu kadar sık karşılaşılan ve göreceli olarak aktif nüfusu tutan meme kanserinde hastaların yaşam kalitesini arttırmaya yönelik olarak cerrahi dışında da pek çok tedavi modalitesi geliştirilmektedir. Son 20 yıl içerisinde meme kanserinin önlenmesi ve meme kanseri tanıs1 konulan hastalarda yaşam kalitesinin arttırılmasında egzersiz ve fiziksel aktivitenin etkisini araştıran çalışmalar yapılmış olsa da çalışmaların büyük çoğunluğunda metastazı olan hastalar çalışma dişı bırakılmıştır $(2,7,8)$. Metastaz olan bölgeler içerisinde egzersiz ve fiziksel aktiviteyi en yüksek düzeyde etkileyebilecek kemik metastazının mevcut olduğu hasta grubu ile yapılmış çalışmalara ise literatürde yeterince rastlanılmamaktadır. Çalışmamızda kemik metastazı olan meme kanserli hastalarda fiziksel aktivite düzeyi ve yaşam kalitesinin değerlendirilmesi amaçlanmaktadır.

\section{GEREC ve YÖNTEM}

Çalışmamız üniversite yerel etik kurul onayının alınmasını takiben iki farklı üniversite hastanesinde prospektif olarak düzenlenen kesitsel bir çalışmadır. 15.08.2018-15.10.2018 tarihleri arasında çalışmaya dahil olan ilgili branş hekimlerinin de aktif olarak çalışmakta olduğu meme kliniği tarafından takip edilen ve meme kanseri tanısı almış 100 hasta çalışmaya dahil edilmiştir. Hastalar kemik metastazı olan ve olmayan katılımcilar olarak 2 grupta değerlendirilmiştir. Çalışmada kemik metastazı olan ve olmayan hastaların fiziksel aktivite düzeylerinin ortopedik açıdan değerlendirilmesi için hastalar ortopedi uzmanına yönlendirilmiştir. Hastalara sosyo-demografik bilgilerin yer aldığ 1 anket formu ve fiziksel aktivite düzeylerini saptamak için Uluslararası Fiziksel Aktivite Anketi doldurtulmuştur. Yaşam kalitesinin ölçülmesi için kısa form-36 yaşam kalitesi ölçeğinden faydalanılmıştır. Hastalar gönüllük prensibine göre çalışmaya alınmış olup, çalışmaya katılmayı kabul eden meme kanseri tanısı almış olan tüm hastalar gruplardaki hasta sayısı eşit olacak şekilde basit randomizasyon yöntemi kullanılarak çalışmaya dahil edilmiştir. Çalışmaya dahil edilme kriterleri; gönüllü olmak, patolojik olarak meme kanseri tanısı doğrulanmış olmak, son 6 hafta içerisinde kemoterapötik ajan kullanmamış olmak, son 6 hafta içerisinde radyoterapi almamış olmak, metastatik meme kanseri grubunda en az bir veya daha çok kemikte patolojik kırık riski taşımayan (yüksek gerilim barındıran anatomik bölgelerde metastazı bulunmayan, kemik korteksin \% 50 'sinden daha az tutulum gösteren, radyoterapi ve/veya kemoterapiye dirençli kemik ağrısı bulunmayan hastalar) kemik metastazı bulunmak, belirtilen anket formlarını kendi başına doldurmuş olmak; olarak belirlenmiştir. Çalışma döneminin 3 ay öncesinden itibaren hastaların fiziksel aktivitesini engelleyecek bir travma geçirmiş olan, metastaza bağlı patolojik kırığı bulunan, patolojik kırığa yönelik tedavi almış olan, son 3 ay içerisinde radyoterapi öyküsü bulunan, efor kapasitesini düşürecek kardiyopulmoner bir hastalığ $\breve{1}_{1}$ olan, mental düzeyini etkileyecek santral sinir sistemi tutulumu olan ve ankette cevaplanmamış soru bırakan hastalar çalışmaya dahil edilmemiştir. 


\section{UFAA Kisa Form:}

Hastaların fiziksel aktivite düzeyini saptamak için kullanılan, 9 sorudan oluşan, kendi kendine yapılabilen bir anket formudur. Hastaların son 7 gün içinde yapmış oldukları fiziksel aktivitede tükettikleri zamanla alakalıdır. Türkiye'de geçerlilik ve güvenilirliği 2005 y1lında Öztürk tarafindan yapılmıştır (9). Hastaların fiziksel aktiviteleri; son 7 gün içinde en az 10 dakika fiziksel aktivite (FA) yapıyor olması ölçüt alınarak saptandı. Şiddetli fiziksel aktivite (ŞFA) ile ilgili ağırlık kaldırma, aerobik, kazma, futbol, hızlı bisiklet çevirme gibi aktiviteler dakika cinsinden sorgulanarak hesapland1. Orta dereceli fiziksel aktivite (ODFA) ise hafif yük taşıma, halk oyunları, dans, masa tenisi ya da bowling gibi aktiviteler dakika cinsinden hesaplanarak kaydedildi. Yürüme ve 1 gün boyunca oturma süreleri de dakika olarak hesaplandi.

Toplam Fiziksel Aktivite Skoru (TFA); katılımcıların son 1 haftada yaptıkları şiddetli ve orta düzeyde fiziksel aktivite ile yürüme süreleri aşağıda verilen formüller ile dakika, gün sayısı ve yapılan fiziksel aktiviteye uygun MET-dakika skoru ile çarpılarak (MET$\mathrm{dk} / \mathrm{hafta}$ ) saptand. Bu fiziksel aktiviteler için standart MET değerleri vardır.

Yürüme skoru (MET-dk/hf) $=3.3$ *yürüme süresi* yürüme gün sayıs1

Orta şiddetli aktivite skoru (MET-dk/hf) $=4.0$ * orta şiddetli aktivite süresi $*$ orta şiddetli aktivite yapılan gün sayıs1

Şiddetli aktivite skoru (MET -dk/hf) $=8.0 *$ şiddetli aktivite süresi * şiddetli aktivite yapılan gün sayıs1

Toplam Fiziksel Aktivite skoru (MET-dk/hf) = Yürüme + Orta şiddetli aktivite + Şiddetli aktivite skoru

Hastalar toplam fiziksel aktivite puanlarına göre "düşük, orta ve yüksek" FA yapanlar olmak üzere 3 farklı gruba ayrıldı. Bu gruplara göre hastaların aldıkları puanlar; <600 MET$\mathrm{dk} /$ hafta altında ise; düşük düzeyde fiziksel aktivite, 600-3000 MET-dk/hafta arasında ise; orta düzeyde fiziksel aktivite ve $>3000$ MET$\mathrm{dk} / \mathrm{hafta}$ üzerinde ise; yüksek düzeyde fiziksel aktivite yapmaktadır şeklinde sınıflandırıldı (9)

\section{Kısa Form 36 Yaşam Kalitesi Ölçeği:}

Yaşam kalitesini ölçmek için kullanılan KF-36 çok sık kullanılan bir ölçektir. Bu ölçek 1992 yılında Ware ve arkadaşları tarafından geliştirilmiştir (10). Türkiye'de geçerlik ve güvenirliği ise Koçyiğit ve arkadaşları tarafından yapılmıştır (11). Bu ölçek toplam da 36 maddeden oluşmaktadır. Bu maddeler ile 8 farklı boyut ele alınmaktadır (12).

Bunlar;

1. Fiziksel fonksiyon

2. Sosyal fonksiyon

3. $\quad$ Fiziksel rol güçlüğü

4. Emosyonel rol güçlüğü

5. Ruhsal sağlik

6. Enerji/Vitalite

7. Ağr1

8. Genel sağlık algısı

Ölçeğin 2. sorusu dışında ki sorular hastaların son dört haftada mevcut hallerini dikkate alarak değerlendirme yapmakta iken, ikinci soru hastaların son bir yıl içinde sağlık durumlarında meydana gelen değişiklik algısını dikkate almaktadır. Ölçeğin dördüncü ve beşinci soruları evet/hayır şeklinde cevaplanırken diğer sorular1 Likert tipi derecelendirme ile değerlendirme yapmaktadır. Ölçekten alınan 100 puan sağlik durumunun iyi olduğunu, 0 puan ise sağlı̆̆ın kötü olduğunu ifade etmektedir $(13,14)$.

\section{İstatistiksel analiz}

İstatistiksel değerlendirme için SPSS (Statistical Packet for The Social Science) 22.0 bilgisayar programından faydalanıldı. Çalışmada ki verilerin değerlendirilmesinde; tanımlayıcı istatistiksel yöntemlerden; frekans (n), yüzde (\%), ortalama \pm standart sapma, min (minimum) - max (maksimum), Q25-Q75 (ortanca değerleri ile 1 ve 3'üncü çeyreklik değerleri) kullanıldı. İstatistiksel anlamlılıklar için; Ki-kare $\left(X^{2}\right)$ testi, normal dağılım göstermeyen iki grubun karşılaştırılmasında ise non-parametrik testlerden Mann-Whitney U testi kullanılmıştır. Verilerin normalliği Kolmogorov-Smirnov normallik testi kullanılarak kontrol edildi. Tüm analizler $\% 95$ güven aralığında yapıldı. İstatistiksel olarak anlamlı farklılık için $\mathrm{p}<0.05$ düzeyi anlamlı olarak kabul edildi. 


\section{BULGULAR}

Meme kanseri tanısı almış olan hastaların kemik metastaz1 durumlarının sosyo-demografik özelliklere göre karşılaştırılması Tablo 1'de gösterilmiştir.
Elde edilen bulgulara göre katılımcıların yaş ortalamas1 $53.44 \pm 7.22$ (min:41, $\max : 66$ ) y1 olup, çalıșmaya meme kanseri tanısı almıș olan 100 hasta katılmıştır. Kadın hastaların \%67 $(\mathrm{n}=67)$ 'sinin sigara içmediği, \%20 $(\mathrm{n}=20)^{\prime}$ 'sinin sigara içmeyi bıraktığı, \%13 (n=13)'ünün sigara içtiği saptandı (Tablo 1).

Tablo 1: Hastaların sosyo-demografik özellikleri

\begin{tabular}{|c|c|c|c|}
\hline Değişken & Kategori & $\mathbf{n}$ & $\%$ \\
\hline \multicolumn{2}{|c|}{ Yaş Ort \pm SS(min-max) } & 7.22 & \\
\hline \multirow[t]{3}{*}{ Yaş Grupları } & 41-50 Yaş & 35 & 35.0 \\
\hline & 51-60 Yaş & 40 & 40.0 \\
\hline & $\geq 61$ Yaş & 25 & 25.0 \\
\hline \multirow[t]{2}{*}{ Medeni Durum } & Evli & 75 & 75.0 \\
\hline & Bekar & 25 & 25.0 \\
\hline \multirow[t]{3}{*}{ Gelir } & 2000 ve $\downarrow$ & 65 & 65.0 \\
\hline & $2000-4000$ & 25 & 25.0 \\
\hline & 4000 ve $\uparrow$ & 10 & 10.0 \\
\hline \multirow[t]{4}{*}{ Eğitim Durumu } & İlkokul & 30 & 30.0 \\
\hline & İlköğretim & 35 & 35.0 \\
\hline & Lise & 10 & 10.0 \\
\hline & Üniversite ve $\uparrow$ & 25 & 25.0 \\
\hline \multirow[t]{3}{*}{ Meslek } & Ev hanımı & 65 & 65.0 \\
\hline & Emekli & 20 & 20.0 \\
\hline & Memur & 15 & 15.0 \\
\hline \multirow[t]{2}{*}{ Doğum Şekli } & Normal Doğum & 60 & 60.0 \\
\hline & Sezaryen & 40 & 40.0 \\
\hline \multirow[t]{3}{*}{ Sigara Kullanımı } & Hayır & 67 & 67.0 \\
\hline & Evet & 13 & 13.0 \\
\hline & Biraktım & 20 & 20.0 \\
\hline \multicolumn{2}{|l|}{ Toplam } & & \\
\hline
\end{tabular}

Ort \pm SS: Ortalama \pm standart sapma.

Hastaların vücut kitle indeksi ortalamas1; $29.77 \pm 3.53 \quad$ (min:24.98, $\max : 43.28) \quad \mathrm{kg} / \mathrm{m}^{2}$ olarak bulunmuştur. Katılımcıların kemiğe metastaz durumlarının VKİye göre karşılaştırılması istatistiksel olarak anlamlı farklılık göstermemiştir. Hastaların fiziksel aktivite puan ortalamasının; $828.70 \pm 844.28$ MET-dk/Hafta olduğu saptanmıștır. Kemik metastazı olmayan hastaların kemik metastazı olan hastalara göre fiziksel olarak daha aktif olduğu istatistiksel olarak saptanmıştır $(\mathrm{p}<0.001)$. (Tablo 2). 
Tablo 2: Hastaların kemik metastazı durumlarına göre VKİ ve fiziksel aktivite düzeylerinin karşılaştırılması

\begin{tabular}{|c|c|c|c|c|c|c|c|}
\hline Değişken & Kategori & \multicolumn{2}{|c|}{ KM Var } & \multicolumn{2}{|c|}{ KM Yok } & \multirow[t]{2}{*}{$X^{2}$} & \multirow[t]{2}{*}{$p$} \\
\hline & & $\mathbf{n}$ & $\%$ & $\mathbf{n}$ & $\%$ & & \\
\hline \multicolumn{8}{|c|}{ VKİ Ort $\pm S S(\min -\max ) \quad 29.77 \pm 3.53(24.98-43.28)$} \\
\hline VKİ grup & $18,5-24,9$ & 2 & 33,3 & & 66,7 & \multirow{3}{*}{1,574} & \multirow{3}{*}{0,455} \\
\hline & $25,0-29,9$ & 22 & 53,7 & & 46,3 & & \\
\hline & $\geq 30$ & 24 & 51,1 & & 48,9 & & \\
\hline \multicolumn{8}{|c|}{ Fiziksel Aktivite Puan Ort \pm SS $(\min -\max ) 828.70 \pm 844.28$ (198-3252) } \\
\hline \multirow[t]{3}{*}{ Fiziksel aktivite düzeyi } & Aktif olamayan & 45 & 90,0 & & 10,0 & & \\
\hline & Düşük aktivite & 5 & 12,5 & & 87,5 & 64,500 & $<0.001$ \\
\hline & Yeterli aktivite & ( & 0,0 & & 100,0 & & \\
\hline
\end{tabular}

KM: Kemik metastazı; Ort \pm SS: Ortalama \pm standart sapma; VKİ: Vücut kitle indeksi.

KF-36'nın alt ölçekleri ile ilgili ortalama, standart sapma (SS), minimum-maksimum, ortanca ile 1 ve 3'üncü çeyreklik (Q25-Q75) değerleri her iki grup için de çalış1lmıştır.
Yapılan anketin sonuçlarına göre hastalar en yüksek puanı sosyal fonksiyon (58.75 \pm 22.8$)$ alt ölçeğinden alırken, en düşük puanı ağr1 (45.87 \pm 28.9$)$ alanından almışlardır (Tablo 3).

Tablo 3: Kısa form 36'nın alt ölçeklerinin ortalama \pm standart sapma, minimum, maksimum ve ortanca değerleri

\begin{tabular}{|l|l|l|l|l|}
\hline KF-36'nın alt ölçekleri & Ort $\pm S S$ & Min - Max & Ortanca & Q25- Q75 \\
\hline Fiziksel fonksiyon & $50.50 \pm 40.1$ & $0-100$ & 55 & $0-90$ \\
\hline Fiziksel rol güçlüğü & $52.50 \pm 46.2$ & $0-100$ & 50 & $0-100$ \\
\hline Ağr1 & $45.87 \pm 28.9$ & $0-100$ & 45 & $22.5-74.3$ \\
\hline Genel sağlık & $50.50 \pm 21.3$ & $20-80$ & 50 & $26.2-70$ \\
\hline Vitalite (enerji) & $52.00 \pm 18.8$ & $20-100$ & 50 & $45-67.5$ \\
\hline Sosyal fonksiyon & $58.75 \pm 22.8$ & $12.5-100$ & 56.2 & $50-75$ \\
\hline Emosyonel güçlük & $48.33 \pm 47.9$ & $0-100$ & 33.3 & $0-100$ \\
\hline Mental sağlık & $56.80 \pm 11.6$ & $44-92$ & 56 & $48-60$ \\
\hline
\end{tabular}

KF-36: Kisa form 36, Ort \pm SS: Ortalama \pm standart sapma, Min-Max: Minimum-Maksimum, Q25-Q75:1 ve 3 'üncü çeyreklik değerleri göstermektedir.

Hastaların kemiğe metastaz yapma/yapmama durumlarının KF-36'nın alt ölçeklerine göre karşılaştırılmasında kemik metastazı olmayan hastaların fiziksel fonksiyon, fiziksel rol güçlüğü, ağrı, genel sağlık, vitalite (enerji), sosyal fonksiyon, emosyonel güçlük, mental sağlık puan ortalamalarınınkemik metastazı olan hastalara göre istatistiksel olarak anlamlı derecede yüksek olduğu saptanmıştır $(\mathrm{p}<0.001)$ (Tablo 4). 
Tablo 4: Katılımcıların kemik metastazı durumları ile kısa form 36'nın yaşam kalitesi alt ölçekleri arasındaki ilişkinin karşılaştırılması

\begin{tabular}{|c|c|c|c|c|c|c|}
\hline $\begin{array}{l}\text { KF-36'nın alt } \\
\text { ölçekleri }\end{array}$ & $\begin{array}{l}\text { Kemik } \\
\text { Metastazı } \\
\text { Durumu }\end{array}$ & $n$ & Ort $\pm \mathrm{SS}$ & Min - Max & $X^{2}$ & $p \dagger$ \\
\hline \multirow[t]{2}{*}{ Fiziksel fonksiyon } & Var & 50 & \multirow{2}{*}{$\begin{array}{l}14.00 \pm 18.18 \\
87.00 \pm 14.32\end{array}$} & \multirow{2}{*}{$\begin{array}{l}0-50 \\
60-100\end{array}$} & \multirow{2}{*}{8.808} & \multirow{2}{*}{$<0.001$} \\
\hline & Yok & 50 & & & & \\
\hline \multirow{2}{*}{ Fiziksel rol güçlüğü } & Var & 50 & \multirow{2}{*}{$\begin{array}{l}15.00 \pm 23.14 \\
90.00 \pm 30.30\end{array}$} & \multirow{2}{*}{$\begin{array}{l}0-50 \\
0-100\end{array}$} & \multirow{2}{*}{8.172} & \multirow{2}{*}{$<0.001$} \\
\hline & Yok & 50 & & & & \\
\hline \multirow[t]{2}{*}{ Ăgrı } & Var & 50 & \multirow{2}{*}{$\begin{array}{l}27.00 \pm 17.00 \\
64.75 \pm 25.98\end{array}$} & \multirow{2}{*}{$\begin{array}{l}0-45 \\
25-100\end{array}$} & \multirow{2}{*}{7.000} & \multirow{2}{*}{$<0.001$} \\
\hline & Yok & 50 & & & & \\
\hline \multirow[t]{2}{*}{ Genel sağlık } & Var & 50 & \multirow{2}{*}{$\begin{array}{l}33.50 \pm 13.74 \\
67.50 \pm 12.00\end{array}$} & \multirow{2}{*}{$\begin{array}{l}20-50 \\
50-80\end{array}$} & \multirow{2}{*}{8.595} & \multirow{2}{*}{$<0.001$} \\
\hline & Yok & 50 & & & & \\
\hline \multirow[t]{2}{*}{ Vitalite (enerji) } & Var & 50 & \multirow{2}{*}{$\begin{array}{l}39.50 \pm 13.06 \\
64.50 \pm 15.05\end{array}$} & \multirow{2}{*}{$\begin{array}{l}20-50 \\
45-100\end{array}$} & \multirow{2}{*}{7.152} & \multirow{2}{*}{$<0.001$} \\
\hline & Yok & 50 & & & & \\
\hline \multirow[t]{2}{*}{ Sosyal fonksiyon } & Var & 50 & \multirow{2}{*}{$\begin{array}{l}45.00 \pm 15.57 \\
72.50 \pm 23.14\end{array}$} & \multirow{2}{*}{$\begin{array}{l}25-62.5 \\
12.5-100\end{array}$} & \multirow{2}{*}{7.011} & \multirow{2}{*}{$<0.001$} \\
\hline & Yok & 50 & & & & \\
\hline \multirow[t]{2}{*}{ Emosyonel güçlük } & Var & 50 & \multirow{2}{*}{$\begin{array}{l}3.33 \pm 10.09 \\
93.33 \pm 20.21\end{array}$} & \multirow{2}{*}{$\begin{array}{l}0-33.3 \\
33.3-100\end{array}$} & \multirow{2}{*}{9.439} & \multirow{2}{*}{$<0.001$} \\
\hline & Yok & 50 & & & & \\
\hline \multirow[t]{2}{*}{ Mental sağlık } & Var & 50 & \multirow{2}{*}{$\begin{array}{l}51.60 \pm 4.93 \\
62.00 \pm 13.90\end{array}$} & $48-60$ & & \\
\hline & Yok & 50 & & $44-92$ & 4.539 & $<0.001$ \\
\hline
\end{tabular}

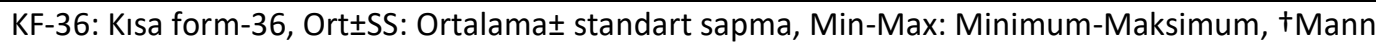

Whitney U testi

\section{TARTIŞMA}

Meme kanseri tanıs1 alan hastalarda, ölümün yaklaştığ düşüncesiyle birlikte ortaya çıkan depresif bulgular hem hastalığa bağl1 semptomların daha hızlı ortaya çıkmasına hem de hastalarda tanı öncesine göre mevcut fiziksel aktivite ve fiziksel kapasitenin düşmesine neden olmaktadır (15-17) Oysa ki sağlık alanında hızla yaşanan gelişmeler meme kanserinde sağ kalımın ve yaşam kalitesinin gittikçe arttığını göstermektedir (2).

Egzersiz ve fiziksel aktivitenin kronik hastalıklardaki etkisi Farrell ve ark. (18) tarafından gösterilmiş ve kronik hastalıklarda egzersizin yaşam kalitesini arttırdığı anlaşılmıştır. Holmes ve ark. (8) ise orta düzey fiziksel aktivitenin meme kanserinde yalnızca yaşam kalitesini değil aynı zamanda da sağ kalımı arttırdığını göstermişlerdir.

Literatürde meme kanseri ile fiziksel aktivite ve egzersiz arasındaki ilişkileri araştıran çalışmalar mevcut olsa da bu çalışmalarda kemik metastazı olan hastaların aktivite düzeyi ve aktivite sonrası bu yaşam kalitesi ve sağ kalım oranları daha önce araştırılmamıştır ve bu hastalar sıklıkla çalışma dışı bırakılmıştır $(7,8, \quad 17,19, \quad 20)$.
Kemik metastazı olan meme kanseri hastalarının ağrı yakınması ve patolojik kırık riski nedeni ile her ne kadar çalışma dış1 bırakılması anlamlı görünse de son dönemde meme kanseri ve kemik metastazının tedavisinde kaydedilen ilerlemeler, patolojik kırık gelişmemişse fiziksel aktivitenin bu hastalar içinde olumlu sonuçlarının olabileceğini düşündürmüștür $(21,22)$. Osteoporoz hastalarında fiziksel aktivitenin olumlu etkileri düşünüldüğünde benzer medikal tedavinin semptomatik amaçlı kullanıldığı bu hastalardaki fiziksel aktivitenin sürdürülebilirliği çalışmamızda araştırılmıştır (23).

Pinto ve ark.'nın (24) yaptığı çalışmada katılımc1 sayıs1 86, Schmitz ve ark'nın (25) yaptığı çalışmada 85, Schwatz ve ark'nın (26) yaptığı çalışmada ise 66 kadın hasta çalışmaya dahil edilmiştir; çalışmamızda 2 farklı grupta 50 'şer hasta olacak şekilde toplamda çalışmaya dahil edilen 100 hastanın literatürle benzer ve yeterli olduğu düşünülmüştür. Yine çalışmaya dahil edilen hastaların yaş ortalamaları yukarıda belirtilen çalışmalarda sırasıyla 53, 53.1 ve 48.2 bulunmuş, çalışmamızda ise yaş ortalamasının 53.44 olduğu ve yapılan çalışmalarla benzer olduğu görülmüştür. 
Yapılan çalışmalarda egzersizin etkisini en iyi gösteren kanıtların fiziksel aktivite ve yaşam kalitesi ölçeği olduğu belirtilmiş olup $(27,28)$ çalışmamızda hem UFAA kısa form hem de kısa form 36 yaşam kalitesi ölçeği tüm katılımcılar tarafindan doldurulmuştur.

Literatürde metastazı olmayan meme kanserli hastalarda; kanser tedavisinin başlaması sonrasında fiziksel aktivite güçlüğü, vitalite ve fiziksel aktivite puanlarının genel olarak düştüğü ancak sosyal fonksiyonun sınırlı çalışmalarda arttığı gösterilmiş $(8,17,27)$; yaşam kalitesinin ve sağ kalımın ise arttığı gözlenmiştir (8). Çalışmamızda kemik metastazı olan hastalarda ağrı puanının belirgin olarak kemik metastazı olmayan gruba göre düşük bulunması, hastalarda metastaz sonras1 oluşan depresif etki ve mental durumda labilite sonucu ağrı eşiğinin düşmesi ile ve metastaza yönelik semptomatik tedavileri etkin olarak almamaları ile açıklanabilir.

Meme kanserli hastalarda fiziksel aktivite yanında doğru medikal tedavi, adjuvan tedaviler (kemoterapi, hormanaterapiler ve aromataz inhibitörleri) hem olas1 kötü semptomların azaltılmasında hem de fiziksel aktivite kapasitesinin arttırılarak daha uzun yaşam süresi elde edilmesinde yardımc olacaktır; Bachelot ve ark.'nın (29) 3. nesil aromataz inhibitörleri ile yaptıkları çalışmalarda; doğru adjuvan tedavinin klinik yararlanım indeksi ve sağ kalım süresini uzattığ görülmüştür.

Çalışmamızda olası limitasyonlar meme kanseri cerrahi tedavisi sonrası ortaya çıkabilecek lenfödemin patolojik kırık gibi dişlama kriterleri içerisinde değerlendirilmemesi, hasta sayısındaki yetersizlik ve olası benzer demografik özelliklere sahip sağl1klı gönüllülerin çalışmaya dahil edilmemesidir. Yine katılımcıların kemiğe metastaz durumlarının VKI'ye göre karşılaştırılması istatistiksel olarak anlamlı farkl1lık göstermemiş olsa da iki gurupta da VKİ yüksek hastaların çalışmaya dahil edilmesinin TFA skorunu etkilemiş olabileceği düşünülmektedir. Bununla birlikte daha sonra daha yüksek hasta katılımı ile yapılacak çalışmalarda grupların kullanılan kemoterapötikler ve aromataz inhibitörlerine göre alt gruplara ayrılması ve bunun sağ kalıma etkisinin incelenmesi ile sonraki çalışmalarda daha kapsamlı sonuçlara ulaşılabilecektir. Çalışmamız izole olarak meme kanserli hastalarda kemik metastazı olan ve olmayan 2 alt grubun kıyaslandığı bir çalışmadır.

Sonuç olarak; çalışmamızda kanser tedavisi almalarına rağmen kemik metastazı olmayan grupta, kemik metastazı olanlara göre fiziksel aktivite ve yaşam kalitesi oranının her kategoride anlamlı olarak yüksek olduğu görülmüş ve patolojik kırıkları olmasa da kemik metastazı sonrası hastaların fiziksel aktivite düzeylerinin ve yaşam kalitesinin düştügü anlaşılmıştır. Literatür 1şı̆̆ında, patolojik kırıkları olmamasına rağmen kemik metastazı olan hastalarda yaşam beklentisindeki azalma ve ölüm düşüncesi olası nedeni ile hastaların fiziksel aktivite kapasitelerinin azaldığ düșünülmektedir. Patolojik kırığı bulunmayan kemik metastazı olan hastalarda ağrı ve metastaza yönelik doğru semptomatik tedavinin fiziksel aktivite ve yaşam kalitesini arttıracağ 1 düşünülmektedir.

Çalışmamızda; istatistik değerlendirme açısından, desteğinden dolayı Uz. Dr. Duygu İlke Yıldırım'a teşekkür ederiz.

Çıkar çatışması: Bildirilmedi

\section{REFERANSLAR}

1. Moulder S, Hortobagyi G. Advances in the treatment of breast cancer. Clinical Pharmacology \& Therapeutics. 2008;83(1):26-36

2. Brown JK, Byers T, Doyle C, Courneya KS, Demark-Wahnefried W, Kushi LH, et al. Nutrition and physical activity during and after cancer treatment: an American Cancer Society guide for informed choices. CA: a cancer journal for clinicians. 2003;53(5):268-91

3. Torre LA, Bray F, Siegel RL, Ferlay J, LortetTieulent J, Jemal A. Global cancer statistics, 2012. CA: a cancer journal for clinicians. 2015;65(2):87108

4. Miller AB, Wall C, Baines CJ, Sun P, To T, Narod SA. Twenty five year follow-up for breast cancer incidence and mortality of the Canadian National Breast Screening Study: randomised screening trial. Bmj. 2014;348:g366

5. Redig AJ, McAllister SS. Breast cancer as a systemic disease: a view of metastasis. Journal of internal medicine. 2013;274(2):113-26

6. Yalçintaş Arslan Ü, Önder Fo, Alkiş N. Meme kanserli hastalarda kemik metastazı tedavisinde bifosfonatlar. Turkish Journal of Oncology/Türk Onkoloji Dergisi. 2011;26(1)

7. Thune I, Furberg A-S. Physical activity and cancer risk: dose-response and cancer, all sites and sitespecific. Medicine and science in sports and 
exercise. 2001;33(6 Suppl):S530-50; discussion S609-10

8. Holmes MD, Chen WY, Feskanich D, Kroenke CH, Colditz GA. Physical activity and survival after breast cancer diagnosis. Jama. 2005;293(20):247986

9. Öztürk M. Üniversitede eğitim-öğretim gören öğrencilerde uluslararası fiziksel aktivite anketinin geçerliliği ve güvenirliği ve fiziksel aktivite düzeylerinin belirlenmesi. Yüksek Lisans Tezi Hacettepe Üniversitesi Sağlık Bilimleri Enstitüsü. 2005

10. Ware Jr JE, Sherbourne CD. The MOS 36-item short-form health survey (SF-36): I. Conceptual framework and item selection. Medical care. 1992:473-83

11. Kocyigit H. Kisa Form-36 (KF-36)'nm Turkce versiyonunun guvenilirligi ve gecerliligi. Ilaç ve tedavi dergisi. 1999;12:102-6

12. Ware Jr JE. SF-36 health survey update. Spine. 2000;25(24):3130-9

13. Heuker D, Lengele B, Delecluse V, Weynand B, Liistro G, Balduyck B, et al. Subjective and objective assessment of quality of life after chest wall resection. European Journal of Cardio-Thoracic Surgery. 2011;39(1):102-8

14. Yıldırım Dİ, Yıldırım A, Eryılmaz MA. Sağlık Çalışanlarında Fiziksel Aktivite İle Yaşam Kalitesi İlişkisinin Değerlendirilmesi. Cukurova Medical Journal.44:1

15. Burgess C, Cornelius V, Love S, Graham J, Richards M, Ramirez A. Depression and anxiety in women with early breast cancer: five year observational cohort study. Bmj. 2005;330(7493):702

16. Fann JR, Thomas-Rich AM, Katon WJ, Cowley D, Pepping M, McGregor BA, et al. Major depression after breast cancer: a review of epidemiology and treatment. General hospital psychiatry. 2008;30(2):112-2

17. Ibrahim EM, Al-Homaidh A. Physical activity and survival after breast cancer diagnosis: meta-analysis of published studies. Medical oncology. 2011;28(3):753-65

18. Farrell SW, Braun L, Barlow CE, Cheng YJ, Blair $\mathrm{SN}$. The relation of body mass index, cardiorespiratory fitness, and all-cause mortality in women. Obesity Research. 2002;10(6):417-23

19. Markes M, Brockow $T$, Resch KL. Exercise for women receiving adjuvant therapy for breast cancer. Cochrane Database of Systematic Reviews. 2006(4)
20. McNeely ML, Campbell KL, Rowe BH, Klassen TP, Mackey JR, Courneya KS. Effects of exercise on breast cancer patients and survivors: a systematic review and meta-analysis. Cmaj. 2006;175(1):34-41

21. Stopeck AT, Lipton A, Body J-J, Steger GG, Tonkin $\mathrm{K}$, De Boer RH, et al. Denosumab compared with zoledronic acid for the treatment of bone metastases in patients with advanced breast cancer: a randomized, double-blind study. Journal of Clinical Oncology. 2010;28(35):5132-9

22. Group EBCTC. Adjuvant bisphosphonate treatment in early breast cancer: meta-analyses of individual patient data from randomised trials. The Lancet. 2015;386(10001):1353-61

23. Castrogiovanni P, Trovato FM, Szychlinska MA, Nsir H, Imbesi R, Musumeci G. The importance of physical activity in osteoporosis. From the molecular pathways to the clinical evidence. Histology and histopathology. 2016;31(11):1183-94

24. Pinto BM, Frierson GM, Rabin C, Trunzo JJ, Marcus $\mathrm{BH}$. Home-based physical activity intervention for breast cancer patients. Journal of clinical oncology. 2005;23(15):3577-87

25. Schmitz KH, Ahmed RL, Hannan PJ, Yee D. Safety and efficacy of weight training in recent breast cancer survivors to alter body composition, insulin, and insulin-like growth factor axis proteins. Cancer Epidemiology and Prevention Biomarkers. 2005;14(7):1672-80

26. Schwartz AL, Winters-Stone $\mathrm{K}$, Gallucci B, editors. Exercise effects on bone mineral density in women with breast cancer receiving adjuvant chemotherapy. Oncology nursing forum; 2007

27. Andria Syka R. The Effect of Exercise in Surviving Patients with Breast Cancer: A Systematic Review. International Journal of Caring Sciences. 2015;8(2):488

28. Atlantis E, Chow C-M, Kirby A, Singh MF. An effective exercise-based intervention for improving mental health and quality of life measures: a randomized controlled trial. Preventive medicine. 2004;39(2):424-34

29. Bachelot T, Bourgier C, Cropet C, Ray-Coquard I, Ferrero J-M, Freyer G, et al. Randomized phase II trial of everolimus in combination with tamoxifen in patients with hormone receptor-positive, human epidermal growth factor receptor 2-negative metastatic breast cancer with prior exposure to aromatase inhibitors: A GINECO study. Journal of Clinical Oncology. 2012;30(22):2718-24 